\title{
Gambaran Bakteri Kontaminan pada Sikat Gigi
}

1) Perdina Nursidika, Patricia Gita Naully, Linda Ayu Lestari

${ }^{1}$ Prodi Analis Kesehatan Stikes Jenderal Achmad Yani Cimahi

*Email: perdina.sidika@gmail.com

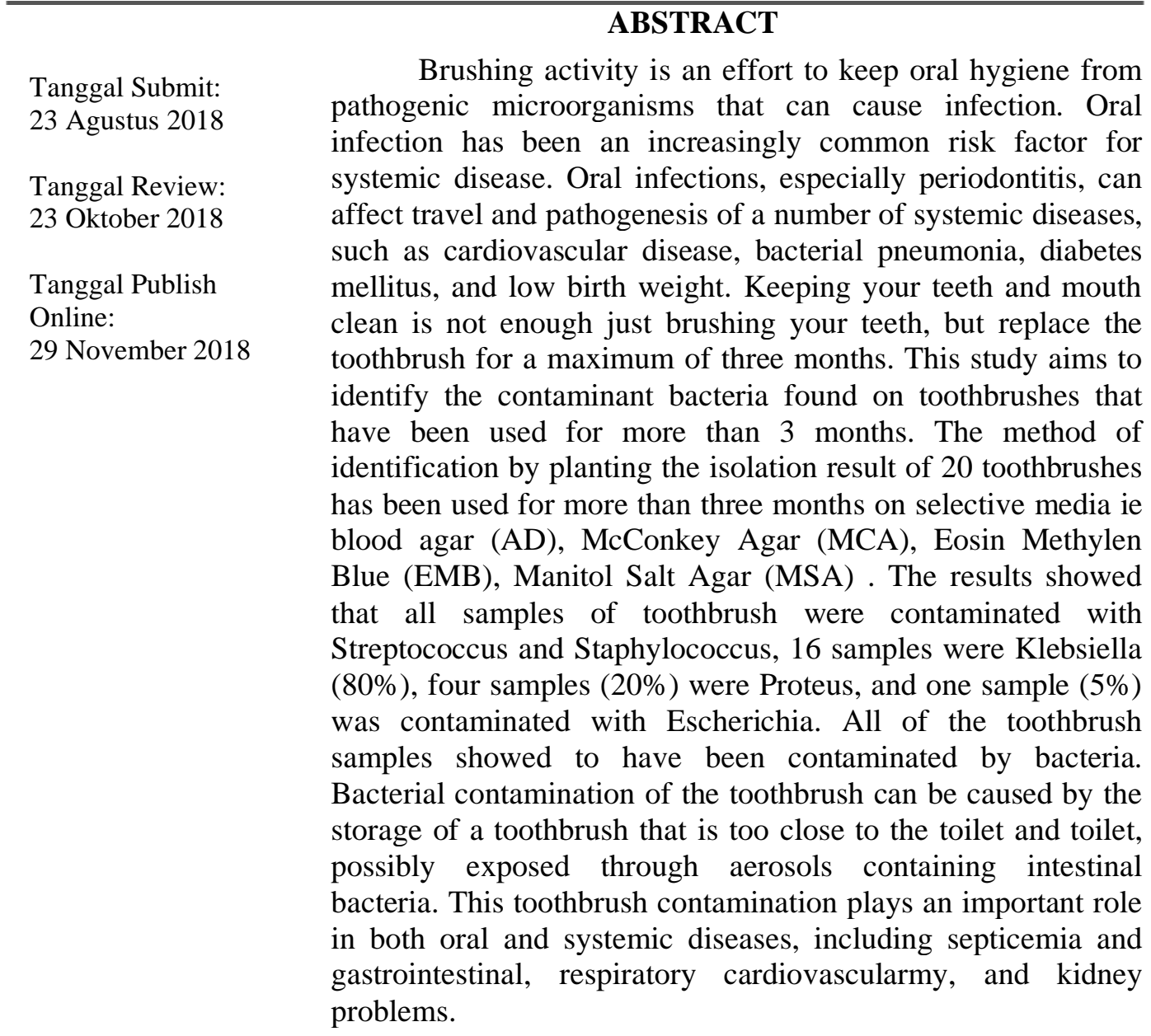

Key words: Bacterial, contamination, toothbrush

\section{PENDAHULUAN}

Di Indonesia penyakit infeksi merupakan penyakit yang sering terjadi baik yang menginfeksi anggota tubuh bagian luar, organ-organ dalam, maupun pada rongga mulut. Penyakit infeksi di Indonesia semakin meningkat pada setiap tahunnya akibat beberapa faktor penyebab, misalnya kesadaran masyarakat akan kebersihan yang kurang (Nursidika, Saptarini, \& Rafiqua, 2014).

Riset Kesehatan Dasar tahun 2013 terhadap perilaku pemeliharaan kesehatan gigi dan mulut (umur $\geq 10$ tahun) dengan jumlah sampel 835.256 responden, dan pemeriksaan gigi serta melihat kondisi gigi dan mulut (umur $\geq 12$ tahun) dengan jumlah sampel 789.771 responden. Hasil riset tersebut 
menyatakan prevalensi nasional masalah gigi dan mulut adalah 25,9 persen, sebanyak 14 provinsi mempunyai prevalensi masalah gigi dan mulut diatas angka nasional (BPPK, 2013).Penyakit gigi dan mulut yang paling umum adalah karies, gingivitis, herpangina, thrush (candidiasis mulut), canker sore (aphthous ulcers), dan herpes mulut.

Di dalam rongga mulut terdapat beberapa jenis mikroorganisme yang merupakan flora normal (Tannock, 1995). Mikroflora normal ini membantu mulut dalam menghambat bakteri eksogen. Adanya mikroflora normal juga dapat menginduksi penyakit mulut seperti karies gigi, penyakit periodontal, dan denture stomatitis. Penyakit tersebut dapat disebabkan oleh kolonisasi mikroflora pada gigi dan gigi palsu. Beberapa mikroorganisme yang bertanggung jawab pada penyakit tersebut antara lain Streptococcus mutans pada karies, Bacteroides gingivalis, Actinobacillus

actinomycetecomitans, spesies

Treponema,dan Candida albicans (Hill \& Marsh, 1989).

Infeksi oral, terutama periodontitis, dapat mempengaruhi perjalanan dan patogenesis dari sejumlah penyakit sistemik, seperti penyakit kardiovaskular, pneumonia bakteri, diabetes mellitus, dan berat badan lahir rendah. Tiga mekanisme atau jalur yang menghubungkan infeksi oral dengan efek sistemik sekunder diduga akibat: 1 . penyebaran penyebaran infeksi dari rongga mulut sebagai akibat dari bakteremia transien, 2. cedera metastasis dari efek sirkulasi racun mikroba mulut, dan 3. peradangan metastatik yang disebabkan oleh cedera imunologis yang disebabkan oleh mikroorganisme oral. Periodontitis sebagai infeksi mulut utama yang dapat mempengaruhi kerentanan penderita terhadap penyakit sistemik dengan tiga cara, yaitu oleh faktor risiko bersama; biofilm subgingival berfungsi sebagai reservoir bakteri gram negatif; dan periodonsium bertindak sebagai reservoir mediator inflamasi (Li, Kolltveit, Tronstad, \& Olsen, 2000).

Oleh sebab itu, harus dilakukan tindakan untuk mencegah terjadinya infeksi dalam rongga mulut. Infeksi mulut telah menjadi faktor risiko yang semakin umum untuk penyakit sistemik, yang harus diperhitungkan oleh dokter. Dokter harus meningkatkan pengetahuan mereka tentang penyakit mulut, dan dokter gigi harus memperkuat pemahaman mereka tentang pengobatan umum, untuk menghindari risiko yang tidak perlu untuk infeksi yang berasal dari mulut (Rautemaa, Lauhio, Cullinan, \& Seymour, 2007). Menjaga kebersihan gigi dan mulut tidak cukup hanya menyikat gigi saja, melainkan 
mengganti sikat gigi maksimal tiga bulan sekali (Notohartojo \& Sihombing, 2015).

\section{Hasil Riset Kesehatan Dasar} Nasional (Riskesdas) tahun 2013 menyebutkan bahwa presentase penduduk yang berperilaku mengganti sikat gigi tiga bulan sekali masih sangat rendah yaitu 7,2\%. Karena rata-rata masyarakat di Indonesia mengganti sikat gigi yang dipakainya hanya satu kali dalam sepuluh bulan. Hal ini juga berakibat terhadap tingginya penyakit pada gigi dan mulut di Indonesia (BPPK, 2013). Jika selama tiga bulan pemakaian sikat gigi tidak diganti maka akan menimbulkan banyak bakteri lalu bulu sikat gigi sudah tidak dapat bekerja dengan baik dan dan dapat melukai gusi (Sariningsih, 2014).

Sikat gigi yang telah digunakan lebih dari tiga bulan adalah tempat yang berpotensi besar untuk berkembangnya bakteri-bakteri (Raiyani et al., 2015). Lima kategori mikroorganisme yang ditemukan dalam sikat gigi adalah mikroorganisme anaerob dan fakultatif, jamur dan ragi, streptococcus oral, enterococcus oral anaerob, Porphyromonas gingivalis, dan spesies Fusobacterium (Advanced Response Corporation, 2014).

Penelitian ini bertujuan untuk mengidentifikasi bakteri kontaminan yang terdapat pada pada sikat gigi yang telah digunakan selama lebih dari 3 bulan.

\section{METODE}

Penelitian ini menggunakan metode deskriptif, yaitu mengidentifikasi bakteri pada sikat gigi yang telah digunakan selama lebih dari 3 bulan. Data penelitian ini berasal dari hasil wawancara, observasi dan pemeriksaan laboratorium.

\section{Sampel Sikat Gigi}

Sampel yang digunakan dalam penelitian ini adalah sebanyak 20 sikat gigi yang telah digunakan lebih dari 3 bulan. Setiap sikat gigi dibersihkan dengan air mengalir dan ditransportasikan ke laboratorium menggunakan tempat sterol. Tempat steril yang terbuka ditutup menggunakan kapas steril untuk mencegah kontaminasi dari udara.

\section{Identifikasi Bakteri}

Sikat gigi Dimasukkan yang telah digunakan lebih dari 3 bulan ke dalam tabung yang berisi Tryptic Soy Broth (TSB) $10 \mathrm{ml}$. Lalu diinkubasi tabung tersebut selama 30 menit. Setelah diinkubasi lalu divortek tabung tersebut selama 60 detik. Setelah divortek, ditanam kedalam media selektif yaitu agar darah (AD), McConkey Agar (MCA), Eosin Methylen Blue (EMB), Manitol Salt Agar (MSA) dengan metode gores. Lalu diinkubasi dengan 
suhu $30^{\circ} \mathrm{c}$ selama 24 jam. Dan diamati koloninya (Samuel \& Ifeanyi, 2015). Koloni diambil dan dilakukan pewarnaan sederhana.

\section{HASIL}

Dari hasil penelitian identifikasi bakteri yang terdapat pada sikat gigi yang telah digunakan lebih dari 3 bulan didapatkan hasil positif untuk semua sampel dengan menggunakan media selektif yaitu AD, MSA, MCA, dan EMB. Dan menggunakan media penyubur yaitu TSB. Sikat gigi yang baru yang belum digunakan berfungsi sebagai kontrol tidak menunjukkan pertumbuhan bakteri. Kontaminasi sikat gigi oleh bakteri bisa berasal dari rongga mulut, wadah penyimpanan, lingkungan penyimpanan, air yang digunakan untuk pembilasan.

Sikat gigi tersebut diinkubasi pada media TSB. Setelah proses inkubasi pada TSB, dilakukan penanaman ke media selektif yaitu AD, MCA, MSA, dan EMB. Setelah proses inkubasi pada suhu $37^{\circ} \mathrm{c}$ selama 24 jam tampak koloni bakteri berbentuk bulat, ukuran 2-4 mm, cembung, rata, berwarna putih, merah muda, ungu, dan jernih. Bentuk koloni yang dilakukan untuk pewarnaan sederhana didapat koloni berbentuk coccus atau bulat bersusunan diplococcus dan basil atau batang bersusunan berantai.Setelah isolat diidentifikasi, ditemukan spesies bakteri Streptococcus sp, Klebsiella $s p$, Staphylococcus sp, Proteus sp, dan Escherichia sp. Hasil dapat dilihat pada tabel 2.

Hasil penelitian 20 dari 20 sampel sikat gigi yang mengandung Streptococcus sp. Bakteri ini merupakan grup yang cukup invasif dalam menyebabkan patogenisitas.

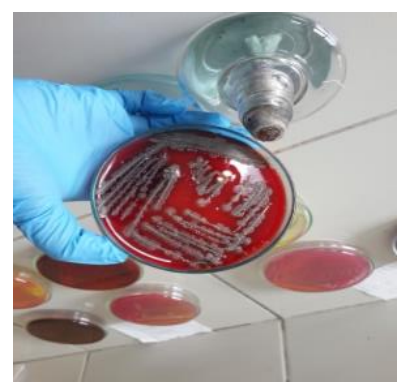

Gambar 1. Hasil Penanaman pada AD

Hasil isolasi pada media AD, MCA, MSA, dan EMB diperoleh hasil bahwa terdapat 16 dari 20 sampel yang mengandung Klebsiella sp. Klebsiella adalah bakteri Gram negatif, berbentuk batang yang bersifat fakultatif anaerob, ditemukan sebagai flora normal di mulut, kulit, dan usus (Guo et al., 2012).

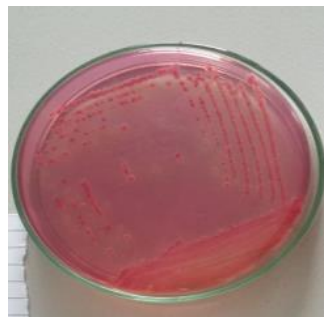

Gambar 2. Hasil Penanaman pada MC Agar 
Tabel 1 Hasil Kontrol Positif dan Negatif

\begin{tabular}{|c|c|c|c|c|c|c|}
\hline \multirow[t]{2}{*}{ kontrol } & \multicolumn{4}{|c|}{ Media } & \multirow{2}{*}{$\begin{array}{l}\text { Pada } \\
\text { pewarnaan } \\
\text { sederhana }\end{array}$} & \multirow[t]{2}{*}{ Tersangka } \\
\hline & $\mathrm{AD}$ & $\mathrm{MCA}$ & MSA & EMB & & \\
\hline $\begin{array}{l}\text { Kontrol } \\
\text { positif }\end{array}$ & $\beta$ hemolisis. & $\begin{array}{l}\text { Tidak } \\
\text { tumbuh } \\
\text { bakteri. }\end{array}$ & $\begin{array}{l}\text { Manitol } \\
\text { fermenter. }\end{array}$ & $\begin{array}{l}\text { Tidak } \\
\text { tumbuh } \\
\text { bakteri. }\end{array}$ & $\begin{array}{l}\text { AD: Coccus, } \\
\text { diplococcus. } \\
\text { MCA: - } \\
\text { MSA: Coccus, } \\
\text { berantai. } \\
\text { EMB: - }\end{array}$ & $\begin{array}{l}\text { AD: } \\
\text { Streptococcus sp } \\
\text { MCA: - } \\
\text { MSA: } \\
\text { Staphylococcus } \\
\text { sp, } \\
\text { EMB: - }\end{array}$ \\
\hline $\begin{array}{l}\text { kontrol } \\
\text { negatif }\end{array}$ & $\begin{array}{l}\text { Tidak } \\
\text { tumbuh } \\
\text { balteri }\end{array}$ & $\begin{array}{l}\text { Tidak } \\
\text { tumbuh } \\
\text { bakteri. }\end{array}$ & $\begin{array}{l}\text { Tidak } \\
\text { tumbuh } \\
\text { balteri. }\end{array}$ & $\begin{array}{l}\text { Tidak } \\
\text { tumbuh } \\
\text { bakteri. }\end{array}$ & $\begin{array}{l}\text { AD: - } \\
\text { MSA : } \\
\text { MCA: - } \\
\text { EMB: - }\end{array}$ & $\begin{array}{l}\text { AD: - } \\
\text { MCA: - } \\
\text { MSA: - } \\
\text { EMB: - }\end{array}$ \\
\hline
\end{tabular}

Tabel 2 Hasil Indentifikasi Bakteri pada Sikat Gigi

\begin{tabular}{|c|c|c|c|c|c|c|}
\hline \multirow{2}{*}{$\begin{array}{c}\text { Kode } \\
\text { Sampel }\end{array}$} & \multicolumn{4}{|c|}{ Media } & \multirow{2}{*}{$\begin{array}{c}\text { Pada } \\
\text { pewarnaan } \\
\text { sederhana }\end{array}$} & \multirow[b]{2}{*}{ Tersangka } \\
\hline & AD & MCA & MSA & EMB & & \\
\hline 01 & $\begin{array}{c}\beta \\
\text { hemolisis. }\end{array}$ & $\begin{array}{l}\text { Laktosa } \\
\text { fermenter. }\end{array}$ & $\begin{array}{c}\text { Manitol } \\
\text { fermenter. }\end{array}$ & $\begin{array}{l}\text { Ungu, } \\
\text { tidak ada } \\
\text { kemilau. }\end{array}$ & $\begin{array}{c}\text { AD: Coccus, } \\
\text { diplococcus. } \\
\text { MCA: Basil, } \\
\text { berpasangan. } \\
\text { MSA: Coccus, } \\
\text { berantai. } \\
\text { EMB: Basil, } \\
\text { diplobasil. }\end{array}$ & $\begin{array}{c}\text { AD: } \\
\text { Streptococcus } \\
\text { sp } \\
\text { MCA: } \\
\text { Klebsiella sp, } \\
\text { MSA: } \\
\text { Staphylococcus } \\
\text { sp, } \\
\text { EMB: } \\
\text { Klebsiella sp }\end{array}$ \\
\hline 02 & $\begin{array}{c}\beta \\
\text { hemolisis. }\end{array}$ & $\begin{array}{c}\text { Non } \\
\text { laktosa } \\
\text { fermenter. }\end{array}$ & $\begin{array}{c}\text { Manitol } \\
\text { fermenter. }\end{array}$ & $\begin{array}{l}\text { Ungu, } \\
\text { tidak ada } \\
\text { kemilau. }\end{array}$ & $\begin{array}{l}\text { AD: Coccus, } \\
\text { diplococcus. } \\
\text { MCA: Basil, } \\
\text { berasangan. } \\
\text { MSA: Coccus, } \\
\text { diplococcus. } \\
\text { EMB: Basil, } \\
\text { diplobasil. }\end{array}$ & $\begin{array}{c}\text { AD: } \\
\text { Streptococcus } \\
\text { sp } \\
\text { MCA: Proteus } \\
\text { sp, MSA: } \\
\text { Staphylococcus } \\
\text { sp, } \\
\text { EMB: } \\
\text { Klebsiella } s p\end{array}$ \\
\hline 03 & $\beta$ & Laktosa & Manitol & Ungu, & AD: Coccus, & AD: \\
\hline
\end{tabular}




\begin{tabular}{|c|c|c|c|c|c|c|}
\hline & hemolisis. & fermenter. & fermenter. & $\begin{array}{l}\text { tidak ada } \\
\text { kemilau. }\end{array}$ & $\begin{array}{c}\text { diplococcus. } \\
\text { MCA: Basil, } \\
\text { berpasangan. } \\
\text { MSA: Coccus, } \\
\text { berantai. } \\
\text { EMB: Basil, } \\
\text { diplobasil. }\end{array}$ & $\begin{array}{c}\text { Streptococcus } \\
\text { sp } \\
\text { MCA: } \\
\text { Klebsiella sp, } \\
\text { MSA: } \\
\text { Staphylococcus } \\
s p, \\
\text { EMB: } \\
\text { Klebsiella } s p \\
\end{array}$ \\
\hline 04 & $\begin{array}{c}\beta \\
\text { hemolisis. }\end{array}$ & $\begin{array}{l}\text { Laktosa } \\
\text { fermenter. }\end{array}$ & $\begin{array}{l}\text { Manitol } \\
\text { fermenter. }\end{array}$ & $\begin{array}{l}\text { Halus, } \\
\text { transparan } \\
\text { tidak } \\
\text { bewarna. }\end{array}$ & $\begin{array}{l}\text { AD: coccus, } \\
\text { diplococus. } \\
\text { MSA:coccus, } \\
\text { berantai. } \\
\text { MCA:basil, } \\
\text { perpasangan } \\
\text { EMB:basil, } \\
\text { perpasangan. }\end{array}$ & $\begin{array}{c}\text { AD: } \\
\text { Streptococcus } \\
\text { sp } \\
\text { MCA: } \\
\text { Klebsiella sp, } \\
\text { MSA: } \\
\text { Staphylococcus } \\
\text { sp, } \\
\text { EMB: Proteus } \\
\text { sp }\end{array}$ \\
\hline 05 & $\begin{array}{l}\beta \\
\text { hemolisis. }\end{array}$ & $\begin{array}{l}\text { Laktosa } \\
\text { fermenter. }\end{array}$ & $\begin{array}{l}\text { Manitol } \\
\text { fermenter. }\end{array}$ & $\begin{array}{l}\text { Halus, } \\
\text { transparan } \\
\text { tidak } \\
\text { bewarna. }\end{array}$ & $\begin{array}{l}\text { AD: coccus, } \\
\text { diplococus. } \\
\text { MSA:coccus, } \\
\text { berantai. } \\
\text { MCA:basil, } \\
\text { perpasangan. } \\
\text { EMB:basil, } \\
\text { perpasangan. }\end{array}$ & $\begin{array}{c}\text { AD: } \\
\text { Streptococcus } \\
\text { sp } \\
\text { MCA: } \\
\text { Klebsiella sp, } \\
\text { MSA: } \\
\text { Staphylococcus } \\
\text { sp, } \\
\text { EMB: Proteus } \\
\text { sp }\end{array}$ \\
\hline 06 & $\begin{array}{l}\beta \\
\text { hemolisis. }\end{array}$ & $\begin{array}{l}\text { Laktosa } \\
\text { fermenter. }\end{array}$ & $\begin{array}{l}\text { Manitol } \\
\text { fermenter. }\end{array}$ & $\begin{array}{l}\text { Ungu, } \\
\text { tidak ada } \\
\text { kemilau. }\end{array}$ & $\begin{array}{l}\text { AD: Coccus, } \\
\text { diplococcus. } \\
\text { MCA: Basil, } \\
\text { berpasangan. } \\
\text { MSA: Coccus, } \\
\text { berantai. } \\
\text { EMB: Basil, } \\
\text { diplobasil. }\end{array}$ & $\begin{array}{c}\text { AD: } \\
\text { Streptococcus } \\
\text { sp } \\
\text { MCA: } \\
\text { Klebsiella sp, } \\
\text { MSA: } \\
\text { Staphylococcus } \\
\text { sp, } \\
\text { EMB: } \\
\text { Klebsiella sp }\end{array}$ \\
\hline 07 & $\begin{array}{c}\beta \\
\text { hemolisis. }\end{array}$ & $\begin{array}{c}\text { Non } \\
\text { laktosa } \\
\text { fermenter. }\end{array}$ & $\begin{array}{c}\text { Manitol } \\
\text { fermenter. }\end{array}$ & $\begin{array}{l}\text { Ungu, } \\
\text { tidak ada } \\
\text { kemilau. }\end{array}$ & $\begin{array}{l}\text { AD: Coccus, } \\
\text { diplococcus. } \\
\text { MCA: Basil, } \\
\text { berasangan. } \\
\text { MSA: Coccus, } \\
\text { diplococcus.. } \\
\text { EMB: Basil, } \\
\text { diplobasil. }\end{array}$ & $\begin{array}{c}\text { AD: } \\
\text { Streptococcus } \\
\text { sp } \\
\text { MCA: Proteus } \\
\text { sp, MSA: } \\
\text { Staphylococcus } \\
\text { sp, } \\
\text { EMB: } \\
\text { Klebsiella } s p \\
\end{array}$ \\
\hline 08 & $\begin{array}{c}\beta \\
\text { hemolisis. }\end{array}$ & $\begin{array}{c}\text { Non } \\
\text { laktosa } \\
\text { fermenter. }\end{array}$ & $\begin{array}{c}\text { Manitol } \\
\text { fermenter. }\end{array}$ & $\begin{array}{l}\text { Ungu, } \\
\text { tidak ada } \\
\text { kemilau. }\end{array}$ & $\begin{array}{l}\text { AD: Coccus, } \\
\text { diplococcus. } \\
\text { MCA: Basil, }\end{array}$ & $\begin{array}{c}\text { AD: } \\
\text { Streptococcus } \\
s p\end{array}$ \\
\hline
\end{tabular}




\begin{tabular}{|c|c|c|c|c|c|c|}
\hline & & & & & $\begin{array}{l}\text { berasangan. } \\
\text { MSA: Coccus, } \\
\text { diplococcus. } \\
\text { EMB: Basil, } \\
\text { diplobasil. }\end{array}$ & $\begin{array}{l}\text { MCA: Proteus } \\
\text { sp, MSA: } \\
\text { Staphylococcus } \\
\text { sp, } \\
\text { EMB: } \\
\text { Klebsiella } s p\end{array}$ \\
\hline 09 & $\begin{array}{c}\beta \\
\text { hemolisis. }\end{array}$ & $\begin{array}{l}\text { Laktosa } \\
\text { fermenter. }\end{array}$ & $\begin{array}{c}\text { Manitol } \\
\text { fermenter. }\end{array}$ & $\begin{array}{c}\text { Bewarna } \\
\text { gelap dan } \\
\text { terdapat } \\
\text { hijau } \\
\text { metalik }\end{array}$ & $\begin{array}{l}\text { AD: Coccus, } \\
\text { diplococcus. } \\
\text { MCA: Basil, } \\
\text { berpasangan. } \\
\text { MSA: Coccus, } \\
\text { berantai. } \\
\text { EMB: Basil, } \\
\text { berpasangan. }\end{array}$ & $\begin{array}{c}\text { AD: } \\
\text { Streptococcus } \\
\text { sp } \\
\text { MCA: } \\
\text { Klebsiella sp, } \\
\text { MSA: } \\
\text { Staphylococcus } \\
\text { sp, } \\
\text { EMB: } \\
\text { Escherichia sp }\end{array}$ \\
\hline 10 & $\begin{array}{c}\beta \\
\text { hemolisis. }\end{array}$ & $\begin{array}{c}\text { Laktosa } \\
\text { fermenter. }\end{array}$ & $\begin{array}{c}\text { Manitol } \\
\text { fermenter. }\end{array}$ & $\begin{array}{l}\text { Ungu, } \\
\text { tidak ada } \\
\text { kemilau. }\end{array}$ & $\begin{array}{l}\text { AD: Coccus, } \\
\text { diplococcus. } \\
\text { MCA: Basil, } \\
\text { berpasangan. } \\
\text { MSA: Coccus, } \\
\text { berantai. } \\
\text { EMB: Basil, } \\
\text { diplobasil. }\end{array}$ & $\begin{array}{c}\text { AD: } \\
\text { Streptococcus } \\
\text { sp } \\
\text { MCA: } \\
\text { Klebsiella sp, } \\
\text { MSA: } \\
\text { Staphylococcus } \\
\text { sp, } \\
\text { EMB: } \\
\text { Klebsiella } s p\end{array}$ \\
\hline 11 & $\begin{array}{c}\beta \\
\text { hemolisis. }\end{array}$ & $\begin{array}{c}\text { Laktosa } \\
\text { fermenter. }\end{array}$ & $\begin{array}{c}\text { Manitol } \\
\text { fermenter. }\end{array}$ & $\begin{array}{l}\text { Ungu, } \\
\text { tidak ada } \\
\text { kemilau. }\end{array}$ & $\begin{array}{l}\text { AD: Coccus, } \\
\text { diplococcus. } \\
\text { MCA: Basil, } \\
\text { berpasangan. } \\
\text { MSA: Coccus, } \\
\text { berantai. } \\
\text { EMB: Basil, } \\
\text { diplobasil. }\end{array}$ & $\begin{array}{c}\text { AD: } \\
\text { Streptococcus } \\
\text { sp } \\
\text { MCA: } \\
\text { Klebsiella sp, } \\
\text { MSA: } \\
\text { Staphylococcus } \\
\text { sp, } \\
\text { EMB: } \\
\text { Klebsiella sp }\end{array}$ \\
\hline 12 & $\begin{array}{c}\beta \\
\text { hemolisis. }\end{array}$ & $\begin{array}{c}\text { Non } \\
\text { laktosa } \\
\text { fermenter. }\end{array}$ & $\begin{array}{l}\text { Manitol } \\
\text { fermenter. }\end{array}$ & $\begin{array}{l}\text { Ungu, } \\
\text { tidak ada } \\
\text { kemilau. }\end{array}$ & $\begin{array}{l}\text { AD: Coccus, } \\
\text { diplococcus. } \\
\text { MCA: Basil, } \\
\text { berasangan. } \\
\text { MSA: Coccus, } \\
\text { diplococcus. } \\
\text { EMB: Basil, } \\
\text { diplobasil. }\end{array}$ & $\begin{array}{c}\text { AD: } \\
\text { Streptococcus } \\
\text { sp } \\
\text { MCA: Proteus } \\
\text { sp, MSA: } \\
\text { Staphylococcus } \\
s p, \\
\text { EMB: } \\
\text { Klebsiella } s p\end{array}$ \\
\hline 13 & $\begin{array}{c}\beta \\
\text { hemolisis. }\end{array}$ & $\begin{array}{c}\text { Non } \\
\text { laktosa } \\
\text { fermenter. }\end{array}$ & $\begin{array}{c}\text { Manitol } \\
\text { fermenter. }\end{array}$ & $\begin{array}{l}\text { Ungu, } \\
\text { tidak ada } \\
\text { kemilau. }\end{array}$ & $\begin{array}{l}\text { AD: Coccus, } \\
\text { diplococcus. } \\
\text { MCA: Basil, } \\
\text { berpasangan. } \\
\text { MSA: Coccus, } \\
\text { berantai. } \\
\text { EMB: Basil, }\end{array}$ & $\begin{array}{c}\text { AD: } \\
\text { Streptococcus } \\
\text { sp } \\
\text { MCA: } \\
\text { Klebsiella sp, } \\
\text { MSA: } \\
\text { Staphylococcus }\end{array}$ \\
\hline
\end{tabular}




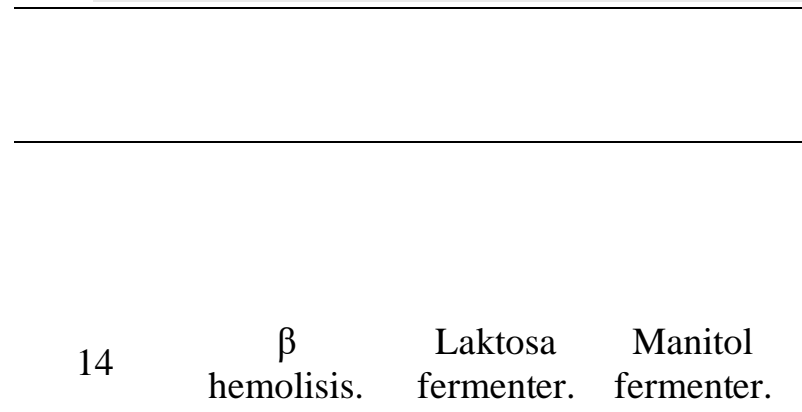

hemolisis. fermenter. fermenter.
Ungu, tidak ada kemilau. berpasangan. diplococcus. MCA: Basil, berpasangan. MSA: Coccus, berantai. EMB: Basil, diplobasil.

Escherichia sp AD:

Streptococcus

$$
\text { sp }
$$

MCA:

Klebsiella sp, MSA:

Staphylococcus $s p$, EMB:

Klebsiella sp

Ungu, 15 $\begin{array}{ccc}\beta & \text { Laktosa } & \text { Manitol } \\ \text { hemolisis. } & \text { fermenter. } & \text { fermenter. }\end{array}$ tidak ada kemilau.
AD: Coccus, diplococcus. MCA: Basil, berpasangan.
MSA: Coccus, berantai.

EMB: Basil, diplobasil.
AD:

Streptococcus

sp

MCA:

Klebsiella sp,

MSA:

Staphylococcus

$s p$,

EMB:

Klebsiella sp

AD: Coccus, diplococcus. MCA: Basil, berpasangan.

MSA: Coccus, berantai.

AD:

Streptococcus

$s p$

MCA:

Ungu, tidak ada kemilau.

Klebsiella sp,

MSA:
EMB: Basil, diplobasil.
Staphylococcus $s p$,

EMB:

Klebsiella sp

$17 \quad \beta \quad$ Laktosa $\quad$ Manitol hemolisis. fermenter. fermenter.
AD: Coccus, diplococcus. MCA: Basil, berpasangan.

Ungu, tidak ada

kemilau.
MSA: Coccus, berantai.

EMB: Basil, diplobasil.
AD:

Streptococcus

sp

MCA:

Klebsiella sp, MSA:

Staphylococcus $s p$,

EMB:

Klebsiella $s p$ $\mathrm{AD}$ :

Streptococcus diplococcus. MCA: Basil, Ungu, berpasangan. tidak ada MSA: Coccus, kemilau. berantai.

EMB: Basil, diplobasil. sp

MCA:

Klebsiella sp, MSA:

Staphylococcus $s p$, EMB: 
Klebsiella sp

\begin{tabular}{|c|c|c|c|c|c|c|}
\hline 19 & $\begin{array}{c}\beta \\
\text { hemolisis. }\end{array}$ & $\begin{array}{c}\text { Laktosa } \\
\text { fermenter. }\end{array}$ & $\begin{array}{l}\text { Manitol } \\
\text { fermenter. }\end{array}$ & $\begin{array}{l}\text { Ungu, } \\
\text { tidak ada } \\
\text { kemilau. }\end{array}$ & $\begin{array}{l}\text { AD: Coccus, } \\
\text { diplococcus. } \\
\text { MCA: Basil, } \\
\text { berpasangan. } \\
\text { MSA: Coccus, } \\
\text { berantai. } \\
\text { EMB: Basil, } \\
\text { diplobasil. }\end{array}$ & $\begin{array}{c}\text { AD: } \\
\text { Streptococcus } \\
s p \\
\text { MCA: } \\
\text { Klebsiella sp, } \\
\text { MSA: } \\
\text { Staphylococcus } \\
\text { sp, } \\
\text { EMB: } \\
\text { Klebsiella sp } \\
\end{array}$ \\
\hline 20 & $\begin{array}{c}\beta \\
\text { hemolisis. }\end{array}$ & $\begin{array}{c}\text { Laktosa } \\
\text { fermenter. }\end{array}$ & $\begin{array}{l}\text { Manitol } \\
\text { fermenter. }\end{array}$ & $\begin{array}{l}\text { Ungu, } \\
\text { tidak ada } \\
\text { kemilau. }\end{array}$ & $\begin{array}{l}\text { AD: Coccus, } \\
\text { diplococcus. } \\
\text { MCA: Basil, } \\
\text { berpasangan. } \\
\text { MSA: Coccus, } \\
\text { berantai. } \\
\text { EMB: Basil, } \\
\text { diplobasil. }\end{array}$ & $\begin{array}{c}\text { AD: } \\
\text { Streptococcus } \\
\text { sp } \\
\text { MCA: } \\
\text { Klebsiella sp, } \\
\text { MSA: } \\
\text { Staphylococcus } \\
\text { sp, } \\
\text { EMB: } \\
\text { Klebsiella sp }\end{array}$ \\
\hline
\end{tabular}


The Joumal Of Muhammadiyah Medical Laboratory Technologist

Vol.2 No. 1, November 2018

p-ISSN:2597-3681 e-ISSN:26142805

Semua sampel sikat gigi mengandung Escherichia sp.

terkontaminasi Staphylococcus $s p$.

Escherichia $s p$ adalah bakteri dari

Staphylococcus adalah sel yang anggota family Enterobacteriaceae. berbentuk bulat dengan diameter $1 \mu \mathrm{m}$ Ukuran sel dengan panjang 2,0-6,0 $\mu \mathrm{m}$ yang tersusun dalam bentuk kluster yang tidak teratur. Kokus tunggal, berpasangan, tetrad, dan berbentuk rantai juga tampak dalam biakan cair (Monteiro et al., 2015).

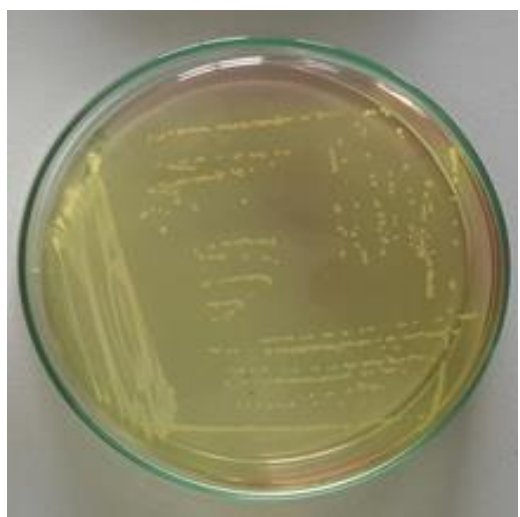

Gambar 3. Hasil Penanaman pada MSA

Hasil penelitian Proteus $s p$ terdapat pada empat dari 20 sampel sikat gigi. Proteus $s p$ termasuk dalam famili enterobacteriaceae, bakteri bentuk batang, Gram negatif, tidak berspora, tidak berkapsul, flagel peritrik, ada yang cocobacilli, polymorph, berpasangan atau membentuk rantai, kuman ini berukuran 0,4-0,8 x 1.0-0,3 mm. Bakteri proteus $s p$ Termasuk dalam bakteri non fruktosa fermenter, bersifat fakultatif anaerob (Fleming, Voureka, Kramer, \& Hughes, 1950).

Hasil isolasi pada media AD, MCA, MSA, dan EMB diperoleh hasil bahwa terdapat 1 dari 20 sampel yang dan lebar $1,1-1,5 \mu \mathrm{m}$. Tidak ditemukan spora. Escherichia adalah bakteri batang Gram negatif (Joshi, 2007).

Pada penelitian ini sekitar 20 sampel sikat gigi yang telah digunakan lebih dari tiga bulan didapatkan hasil bahwa bakteri yang terdapat di semua sampel sikat gigi yaitu Streptococcus dan Staphylococcus, pada 16 sampel (80\%) terdapat Klebsiella, pada 4 sampel (20\%) terdapat Proteus, dan pada 1 sampel (5\%) terdapat Escherichia.

\section{PEMBAHASAN}

Hasil menunjukkan semua sampel sikat gigi yang telah digunakan lebih dari tiga bulan terkontaminasi bakteri Streptococcus Sp. Patogenisitas Streptococcus $S p$ terjadi dengan derajat kerusakan yang disebabkan oleh mikroorganisme dan respon sistem imun terhadap patogen. Streptococcus $s p$ dibagi menjadi 49 spesies dan delapan subspesies, 35 spesies telah diidentifikasi sebagai sumber infeksi invasif pada manusia (Krzyściak, Pluskwa, Jurczak, \& Kościelniak, 2013)(Krzyściak et al., 2013)(Krzyściak, Pluskwa, Jurczak, \& Kościelniak, 2013). 
Streptococcus mutans merupakan spesies yang ada di mulut, spesies ini diketahui menyebabkan karies gigi dengan cara memetabolisme karbohidrat berbeda pada gigi (Moye, Zeng, \& Burne, 2014). Streptococcus mutans dapat masuk ke dalam peredaran darah dan menyebar ke organ tubuh lainnya maka akan merusak organ-organ tubuh tersebut dan menyebabkan berbagai penyakit. Bakteri ini telah diketahui menyebabakan bakterimia dan endokarditis infektif (IE). DNA bakteri ini banyak diidentifikasi pada penyakit kardiovaskular (Nakano, Nomura, \& Ooshima, 2008). Karena berasal dari mulut, kehadiran bakteri pada sikat gigi tidak mengherankan. Pembilasan sikat gigi bekas yang tidak tepat mungkin menyumbang pertumbuhan bakteri pada sampel.

$\begin{array}{rlr}\text { Semua } & \text { sampel sikat gigi } \\ \text { terkontaminasi } & \text { Staphylococcus } & s p .\end{array}$
Staphylococcus secara komensal terdapat di kulit (Chiller, Selkin, \& Murakawa, 2001). Jumlah koloni bakteri di kulit dan mukosa melebihi jumlah yang sel yang dibentuk di tubuh manusia. Bakteri komensal dalam keadaan tertentu dapat menghambat respons imun inang dan menjadi patologis (Tlaskalová-Hogenová et al., 2004) (Tlaskalová-Hogenová et al., 2004) (Tlaskalová-Hogenová et al., 2004).
Adanya Staphylococcus sp pada sikat gigi bekas dalam jumlah tinggi mungkin berasal dari penanganan dan pembilasan sikat gigi setelah digunakan. Staphylococcus $s p \quad$ berpotensi menyebabkan bakterimia yang menyebabkan penyakit pada organ dalam (Bagg, Smith, \& Jackson, 2001).

Empat sampel sikat gigi terkontaminasi Proteus sp. Proteus merupakan flora normal pada usus dan penyebab utama infeksi saluran kemih (Guentzel, 1996). Adanya bakteri ini pada sikat gigi kemungkinan berasal dari kontaminasi aerosol yang berada di kamar mandi (Rao Sukhabogii et al., 2015).

Satu sampel sikat gigi menunjukkan adanya kontaminasi Eschericia sp. Kehadiran Escherichia coli pada sikat gigi yang diperiksa menunjukkan kontaminasi tinja. Sikat gigi harus disimpan di lingkungan yang tidak higienis seperti wastafel toilet dan kamar mandi. Bakteri ini mungkin juga sudah memasuki sikat gigi melalui air pembilas.

Semua sampel sikat gigi menunjukkan telah terkontaminasi oleh bakteri. Kontaminasi bakteri pada sikat gigi ini dapat disebabkan oleh penyimpanan sikat gigi yang terlalu dekat dengan jamban, sehingga kemungkinan terpapar melalui aerosol 
yang mengandung bakteri usus (Taji \&

Rogers, 1998).

Kontaminasi sikat gigi ini memegang peranan penting pada penyakit oral maupun sistemik, termasuk septikemia dan gastrointestinal, kardiovaskular, pernapasan, dan masalah ginjal (Peker, Akca, Sarikir, Alkurt, \& Celik, 2014).

Pentingnya penyimpanan dan penggantian sikat gigi setiap tiga bulan sekali perlu dilakukan untuk mencegah kontaminasi bakteri dalam sikat gigi berefek pada penyakit yang lebih parah. Beberapa penelitian menyarankan desinfeksi sikat gigi dapat mencegah kontaminasi untuk mencegah penyakit. Seperti menggunakan klorheksidine, triklosan maupun larutan cuka (Komiyama, Back-Brito, Balducci, \& Koga-Ito, 2010). Hal ini penting dilakukan terutama untuk anak-anak, lansia, dan pasien yang risiko tinggi, termasuk pasien dengan sistem imun yang disupresi dan yang akan transplantasi organ maupun kemoterapi (Peker dkk., 2014)

Berdasarkan penelitian ini mengatakan bahwa semua sikat gigi yang telah digunakan lebih dari tiga bulan menghasilkan banyak pertumbuhan bakteri, sehingga untuk menimalisasu perumbuhan bakteri pada sikat gigi terdapat beberapa cara yaitu sikat gigi sesekali harus dibilas dengan desinfektan / cairan pencuci (klorheksidin 0,12\%) dan dibiarkan mengering di udara sebelum disimpan dalam wadah kering higienis. Untuk cara penyimpanan sikat gigi, sikat gigi harus disimpan jauh dari kloset, sedangkan untuk waktu pemakaian sikat gigi adalah maksimal sekitar 3 bulan.

\section{SIMPULAN}

\section{Simpulan}

Hasil penelitian menunjukkan semua sampel sikat gigi terkontaminasi Streptococcus dan Staphylococcus, 16 sampel terdapat Klebsiella (80\%), pada empat sampel (20\%) terdapat Proteus, dan satu sampel (5\%) terkontaminasi Escherichia.

\section{DAFTAR PUSTAKA}

Advanced Response Corporation. (2014). Up to 3,000 times the bacterial growth on hollow-head toothbrushes. Diambil 23 Juli 2018, dari https://www.sciencedaily.com/re leases/2014/08/140828115226.h $\underline{\mathrm{tm}}$

Bagg, J., Smith, A. J., \& Jackson, M. S. (2001). The ecology of Staphylococcus species in the oral cavity. Journal of Medical Microbiology, 50(11), 940-946. https://doi.org/10.1099/00221317-50-11-940 
BPPK, K. R. (2013). Riset Kesehatan Dasar 2013.

Chiller, K., Selkin, B. A., \& Murakawa, G. J. (2001). Skin Microflora and Bacterial Infections of the Skin. Journal of Investigative Dermatology Symposium Proceedings, 6(3), 170-174. https://doi.org/10.1046/j.0022202x.2001.00043.x

Fleming, A., Voureka, A., Kramer, I. R. H., \& Hughes, W. H. (1950). The morphology and motility of Proteus vulgaris and other organisms cultured in the presence of penicillin. Microbiology, 4(2), 257-269.

Guo, Y., Cen, Z., Zou, Y., Fang, X., Li, T., Wang, J., ... Liu, C. (2012). Whole-genome sequence of Klebsiella pneumonia strain LCT-KP214. Journal of Bacteriology, 194(12), 3281. https://doi.org/10.1128/JB.0053 1-12

Hill, M. J., \& Marsh, P. D. (1989). Human Microbial Ecology. CRC Press.

Joshi, S. R. (2007). Microbes:redefined Personality. APH Publishing.

Komiyama, E. Y., Back-Brito, G. N., Balducci, I., \& Koga-Ito, C. Y. (2010). Evaluation of alternative methods for the disinfection of toothbrushes. Brazilian Oral Research, 24(1), 28-33. https://doi.org/10.1590/S1806$\underline{83242010000100005}$
Krzyściak, W., Pluskwa, K. K., Jurczak, A., \& Kościelniak, D. (2013). The pathogenicity of the Streptococcus genus. European Journal of Clinical Microbiology \& Infectious Diseases, 32(11), 1361-1376. https://doi.org/10.1007/s10096013-1914-9

Li, X., Kolltveit, K. M., Tronstad, L., \& Olsen, I. (2000). Systemic Diseases Caused by Oral Infection. Clinical Microbiology Reviews, 13(4), 547-558.

Monteiro, J. M., Fernandes, P. B., Vaz, F., Pereira, A. R., Tavares, A. C., Ferreira, M. T., ... Pinho, M. G. (2015). Cell shape dynamics during the staphylococcal cell cycle. Nature Communications, 6.

https://doi.org/10.1038/ncomms 9055

Moye, Z. D., Zeng, L., \& Burne, R. A. (2014). Fueling the caries process: carbohydrate metabolism and gene regulation by Streptococcus mutans. Journal of Oral Microbiology, 6.

https://doi.org/10.3402/jom.v6.2 4878

Nakano, K., Nomura, R., \& Ooshima, T. (2008). Streptococcus mutans and cardiovascular diseases. Japanese Dental Science Review, 44(1), 29-37. https://doi.org/10.1016/j.jdsr.20 $\underline{07.09 .001}$ 
Notohartojo, I. T., \& Sihombing, M. (2015). Faktor Risiko pada Penyakit Jaringan Periodontal Gigi di Indonesia (RISKESDAS 2013) (Risk Factors on Dental Periodontal Tissues Disease in Indonesia [Riskesdas 2013]). Buletin Penelitian Sistem Kesehatan, 18(1). https://doi.org/10.22435/hsr.v18i 1.4274.87-94

Nursidika, P., Saptarini, O., \& Rafiqua, N. (2014). Aktivitas Antimikrob Fraksi Ekstrak Etanol Buah Pinang (Areca catechu L) pada Bakteri Methicillin Resistant Staphylococcus aureus. Majalah Kedokteran Bandung, 46(2), 9499.

Peker, I., Akca, G., Sarikir, C., Alkurt, M. T., \& Celik, I. (2014). Effectiveness of alternative methods for toothbrush disinfection: an in vitro study. TheScientificWorldJournal,

2014 , 726190. https://doi.org/10.1155/2014/72 6190

Raiyani, C. M., Arora, R., Bhayya, D. P., Dogra, S., Katageri, A. A., \& Singh, V. (2015). Assessment of microbial contamination on twice a day used toothbrush head after 1-month and 3 months: An in vitro study. Journal of Natural Science, Biology, and Medicine, 6(Suppl $1)$, S44-S48. https://doi.org/10.4103/0976$\underline{9668.166072}$
Rao Sukhabogii, J., Rudraiah Chandrashekar, B., Haritha, N., Satish Kumar, G., Venkata Ramana, I., Jaya Lakshmi, L., ... Vasundara, D. (2015). Microbial Contamination of Tooth Brushes Stored in Different Settings before and After Disinfection with Chlorhexidine-A Comparative Study. Journal of Young Pharmacists, 7(4s), 486-492. https://doi.org/10.5530/jyp.2015 $.4 \mathrm{~s} .11$

Rautemaa, R., Lauhio, A., Cullinan, M. P., \& Seymour, G. J. (2007). Oral infections and systemic disease - an emerging problem in medicine. Clinical Microbiology and Infection, 13(11), 1041-1047. https://doi.org/10.1111/j.14690691.2007.01802.x

Samuel, O., \& Ifeanyi, O. (2015). Bacterial Contamination of Used Manual Toothbrushes Obtained from Some Students of Nnamdi Azikiwe University Awka, Nigeria. Universal Journal of Microbiology Research, 3(4), 56-59.

https://doi.org/10.13189/ujmr.20 $\underline{15.030404}$

Sariningsih, drg E. (2014). Merawat Gigi Anak Sejak Dini. Elex Media Komputindo. 
Taji, S. S., \& Rogers, A. H. (1998). The microbial contamination of toothbrushes. A pilot study. Australian Dental Journal, 43(2), 128-130. https://doi.org/10.1111/j.18347819.1998.tb06101.x

Tannock, G. W. (1995). Normal Microflora: An Introduction to Microbes Inhabiting the Human Body. Springer Science \& Business Media.
Tlaskalová-Hogenová, H., Štěpánková, R., Hudcovic, T., Tučková, L., Cukrowska, B., LodinováŽádníková, R., ... Kokešová, A. (2004). Commensal bacteria (normal microflora), mucosal immunity and chronic inflammatory and autoimmune diseases. Immunology Letters, 93(2), 97-108. https://doi.org/10.1016/j.imlet.2 004.02.005 